\title{
Organic Food Perspective in Developing Countries: An Overview of Polog Region and a Case Study in the Republic of Macedonia
}

\author{
Ruzhdi Matoshi, PhD \\ University of Business and Technology, Pristina, Republic of Kosovo \\ Besa Veseli, PhD \\ University of Business and Technology, Pristina, Republic of Kosovo
}

\begin{abstract}
Technical and technological advances in food production have brought substantial changes in quantity, quality, diversification and availability of food. The food industry is driven by business activity and objectives, which in turn have considerably affected consumer behavior. While the consumers in general are ready to get adopted and accept the variety of food due to business globalization, thus increasing their preferences to the food that was not available to their vicinity in the past and to the industrial processing such as additives and flavor for extending the duration of consumer durables, a concern has been raised; organic food in a traditional way is healthier. State institutions from their own side have passed many regulations to ensure that food industry and production meets the needed criteria of safety for consumption while businesses compete against each other primarily in making their own way to profit. Yet, an increasing number of consumers worldwide, for their own safety, find it more preferable to undertake a degree of food processing or preparing it on their own. This paper looks at the trend of this consumer behavior in the Polog Region of the Republic of Macedonia, supplemented by a case study of an organic food restaurant located in the city of Tetovo.
\end{abstract}

Keywords: organic food, GM food, Polog region, Porter's five forces, competitive advantage

\section{Introduction}

\section{Organic versus GM food}

Food is a necessity. There is no an alternative to it. Production, demand and consumption of food have constantly been on the rise throughout history, and will continue to experience such a trend in the future as the population grows. Despite technological advancing in mass producing the food, today, a large number of people across the world, especially in developing countries remain poorly fed, facing food shortages and hunger. A considerable number of factors are attributed to the contribution of food crises such as low level of economic development, low incomes per capita, environmental and climatic conditions, unequal disperse of natural resources, the rise in food prices, and the impact of different cultures among the people in consumption and preferential eating habits, e.g. different diets and type of food like organic, conventional and genetically modified food (GMF). Given the undisputable importance of food in general and the rising demand, its production and offering in the market to consumers can be a beneficiary business to be dealt with as well as at the benefits of consumers. In modern times, specialization in offering certain food matters in the market for food.

As the name suggests and by common understanding, organic food is that kind of food that does involvechemical fertilizers and pesticides during the farming process and no food additives while preparing the food. By this definition organic food may also be called as more natural and safer by nutritional value and taste. This has been the main food for people throughout the history until agriculture was industrialized and intensified by the use of various chemicals, or conventional food. The consumers realizing the difference in taste, in response became more aware in favor of organic food, thus initiating the Green Revolution and organic farming movement in the 1940s (Drinkwater, 2009:19). When the food is processed, it should contain the overwhelming majority of organic ingredients. Non-organic ingredients may be present but in fairly small share (up to 5 five percent), be free of food additives with small presence of pesticides if they are not synthetic. Production and processing of organic food is a regulated industry. 
Compared to conventional farming and food, organic based system is believed to healthier for consumers and less damaging to the environment. The most common agreed arguments, which have been tested by surveys, include: i) organic farming by not using pesticides make the environment less prone to harmful effects both in terms of polluting the soil and water; ii) a better choice for the diverse of ecosystems such as various plants, insects and animals than conventional farming; and iii) on average, organic farming can save more the environment as it produces less waste which is caused by throwing of packaging materials such as paper, plastics and metallic waste in which the chemicals are packed (Stolze et al, 2000; Hansen et al, 2001). Perhaps one of the most frequent reasons why organic farming is preferred is that the use of pesticides can have a potential damaging effect in the workers' health.

While organic farming and subsequent organic food is understood to have several benefits, one crucial question that arises about it, is the yield compared to other types such as non-conventional and GMF. The answer is not so easy to be given and justified given the crises of food at global level expressed by hunger and the rise in prices. According to the World Bank estimates, between 2005-2008 food prices have risen by 83 percent, while the demand for food will increase by 50 percent by 2030 (Evans, 2008: 1-2). This is important to have it into consideration, because, majority of the people may find themselves constrained between the alternative of consuming healthier food and the one that is easier to produce, cheaper but with some shortcomings. The studies comparing the yields between organic and other foods offer mix results. As this still requires more research to draw a more clear-cut conclusion, it should be mentioned that the supporters such as Johnston (1986: 102) maintain that, in addition to higher quality due to the soil no so much exposed to pesticides, organic crops and plants have higher probability of retaining water longer, which is important during drought periods, thus more yields. Critics on the other hand base their argument on what is a concern for almost everyone, i.e. more space or land needed for organic farming facing the pressure from rising urbanization which can seriously disrupt the ecosystems in longer run. The problem of available land for organic farming becomes a challenge in small size countries like the Republic of Macedonia, with most land parcels (around 80 percent) scattered in private family ownership whose average size in 2010 was 2.5-2.8 hectares (European Commission, 2011). As the pressure for urbanization is growing, small scattered parcels may further decrease in size, which in turn may constrain the capacities to provide the needed resources to produce organic food, and the skills how to make it more for the market or to a larger number of consumers.

\section{A microeconomic perspective of organic food}

Although organic farming and food appear as traditional, it requires professional research and development. Within the firm level, the key to internal analysis is to identify potential strengths and weaknesses by collecting the relevant information. The analysis should be able to reveal a strategy and an action plan with resources in order to achieve the company's mission and objectives. Internal environment consists of a number of factors as strengths such as resources, capabilities, and competitive advantage with their elements to be valuable, scarce, non-imitable, sustainable, appropriable, have dynamic capabilities and the value chain. Reaping the benefits of strengths involves costs, the main drivers of which are economics of scale, experience effect and value drivers (Fritroy et al, 2012: 213-235). Among the weaknesses can be listed: inefficiency of management or leadership, difficulty to find skilled workers, shortage of financial resources, low technical skills, and investment inefficiency (Abd Gani et al, 2010: 52-53).

When people interact in different parts of the globe or visit other countries, they also get known with locally produced different organic food, and even become addicted to it. The English were used to consume Indian food while serving in India as soldiers and colonizers. After coming back home, Britain welcomed the opening of Indian restaurants by Indian newcomers. This is a case of exporting local cuisine from the colony to the former colonizer. A different example follows in the Republic of Macedonia (especially in the Polog region) during the Ottoman rule that adopted many Turkish based food or recipes. Burek (Turkish pie), doner, baklava (type of homemade sweets), Turkish coffee, Ceylon tea are all of Turkish origin that can be found as the most common food consumed in Polog. The organic food produced from subsistence agriculture for family consumption, begun to reach the public, mostly in the cities, through businesses. The consumers are accustomed to this food in their families. But when they are away at work during the break time or lunch, they may be missing it. A partial fulfillment to the demand for organic food is in the bakeries that can be found in every few hundred meters across the city, and some restaurants more sparsely dispersed.

A huge percentage of population thin the Polog region was always affected by food traditions and rituals which played a crucial part in their lives. However, traditions undergo a change over time by adapting new variety food preferences and eating habits. The dynamics of life in general, has made the citizens to have less time at their disposal for cooking, but 
always in search for value, and willingness to pursue comfort for their body and health. Organic food, when they are not able to prepare it on the own, is their preferred choice.

Porter's five forces is a model for industry analy sis which the manager of a company seeks to develop in gaining competitive advantage over potential rival companies. The rivalry in the market is measured by industry concentration or market share measured by the concentration ratio, which in our case for a restaurant would be the number of restaurants and related businesses. The fiver forces are: i) industry compettors; ii) pressure from substitute products; iii) bargaining power of suppliers; iv) bargaining power of buyers; and potential entrants. In order to gain the advantage over its rivals, the firm in broad terms choses the following policies: changing prices, improving product differentiation, creatively using channels of distribution, and exploiting relationship with the suppliers (Porter, 1980: 215-235). Porter's five forces as general requirements apply to industrial sectors to determine the competition and they can vary within specific industrial sector.

Key Success Factors (KSF), sometime known as Key Performance Indicators (KPI) are the measures by which the success of an industry and the model demonstrates the organizational process or activity to determine the significance of impact on the firm's overall performance. According to Parmenter (2007), these indicators include firm's internal processes such as: unit cost (in currency), yield (in \%), product defects (in \%), process measure (index), staff satisfaction (index), staff skills (index), capabilities (index), productivity (output/employee), and IT system use (index). Given that the firm is an open system influenced by the changes in the environment, the changes are also required in the internal organization as an adoption to the new customer demands, regulations, technological innovation development in communications, transport, and socio-political changes arising from global economic interdependence and integration (Wind and Main, 1998).

A firm can be a pioneer in the market to offer new products and services rather than being an existing one. Pioneer firms require risk-taking initiatives for which they need human and financial resources. They also should innovative and creative. If they lack the capabilities in this respect, they may chose the strategy of fast imitator businesses, i.e. await innovation by the competitors and follow their lead quickly. This alternative is preferable by the firms reluctant or not having the needed resources and skills to innovation. Their advantage is in another crucial aspect - segmentation of the market or better access to the customers. Such firms become more aware in listening or discovering the customer needs, then find the way to respond by acquiring the products from the leaders of innovation (Fitroy et al, 2012: 327-328).

Innovation and research and development (R\&D) as the driving force to business success are associated with risks and costs. Like in any industry, innovation and R\&D in products and services of organic food are a critical issues that involve selection and processing a broad array of organic groceries, fruits, vegetables, and proteins (Godsay, 2010: 22). Risk factors can also be internal. In a typical case of food industry, such risk may be passed to the consumers' health when the food does not meet the needed requirements or its consumption causes health concerns. Food sector is a regulated industry undergoing intensive control of quality by the institutions in charge of monitoring their quality.

The restaurant of organic food is located in the city of Tetovo, the main urban center of the Polog region. The restaurant was established and registered in 2013 as a Joint Stock Company, with 3 co-owners and run by the management. In the first year, the building in which the (first) restaurant was located and operating, was rented for a total cost of $€ 30.000$. Total space of the facility is 160 square meters consisting of $100 \mathrm{~m}^{2}$ indoor, $40 \mathrm{~m}^{2}$ outdoor and $20 \mathrm{~m}^{2}$ kitchen facility. The initial investment was around $€ 100.000$, of which $€ 70,000$ went for renovation and the remaining to run the business in the first three months. More details are provided in Appendix.

Within the first year of operation, the restaurant's first strategic action was to create a value, the value which rests on its mission to provide specific local organic food that currently is scattered in different forms in the market, and plans to assemble it with the aim of becoming exclusive. There is already an abundance of labor force who are women preparing organic food at their homes for their family members, thus there is no need to spend much in this specialization. 


\section{Findings and discussion from the case study}

To begin with capabilities and competitive advantage, it should be noted that the restaurant makes a significant contribution in satisfying the consumer needs that are on the rise in Macedonia (and elsewhere in the world) by first being located in the city where the largest potential customers of the Polog region live. This is the value as internal factor to build a competitive advantage.

Scarce is explained by very limited competition in this kind of food from the rest by not mixing organic food with others. It is a new strategy of shifting away causal and scattered supply of traditional organic food into a more concentrated business by using modern management and environmental friendly technology.

Apart from providing fast hot food in the restaurant itself, the firm has the the services for fast delivery of organic in the surrounding buildings whose employees may not have sufficient time during breakfast and lunch time. Telephone lines are open for customers to order food for delivery in their offices and/or working places in a distance of up to 500 meters from the city center where the restaurant is located. This is a different service and experience with the products that other firms do not yet share or have it organized.

Although the competitors offer and sell similar products, the restaurant is non-imitable in a sense that it uses different routes of supply that is exclusively local to produce the food. The competitors' resources which they use in producing similar food are largely imports from other countries whose origin often remains uncertain as customers usually neither ask where the raw materials are provided from, nor if the base of the food they eat has been subject to conventional farming.

The restaurant is using the initial competitive advantage for a sustainable business in the future. Consumption of organic has long time ago been familiar in Macedonia and will be in the future. As long as organic food is friendly to the environment, its rate of sustainability is higher and lasts longer than in many other industries because, if the people may refrain themselves from the noise of the cars and their gas emissions, they cannot abstain from food consumption.

This business is appropriable as it can appropriate the returns that its capabilities deliver. How this can be explained? The restaurant captures the benefits of its capability in terms of competitive advantage, a part of which are also shared with employees, suppliers and customers. Profit as the primary appropriation goes to the firm. The network of relationships with the customers will mostly go through employees and chefs, not the firm.

Dynamic capabilities of the restaurant in the initial phase may not be a guarantee for success in the future in a fast changing market and environment, but as the competition is weak, current capabilities implies that a particular process has been standardised as a routine that other competitors will find it harder to attain. One of the most useful tools the restaurant as a company will use to assess the capabilities and analyzing business unit, is the value chain or the activities that the restaurant has chosen to compete. These activities involvecosts, and the pressure to lower them. One way of doing so is through economies of scale, i.e. increasing the network and quantity of food to diminish costs per unit. As figures in appendix suggest, in the first year the restaurant had higher costs which gradually decreased the following years as a result of getting stronger position in the market.

New entrants can pose a barrier. Current businesses may expand their activities, a potential barrier to new entries. The barriers to entry in the market can change depending governmental requlations and licensing. Substitutes are the products akin to others within the industry already produced. The reason why substitutes are offered by the firm and consumed by the customers may be either cheaper prices or non-availability of the original products. The purpose of substitutes is to increase the firm's competition in the market where it cannot compete with the same product. Local specific organic produced food by the restaurant is attractive to industry as long as it finds the way to the market. Of particular relevance are the laws regulating organic food and related to gastronomy. The competitors are mainly the bakeries and workshops offering organic food but at the same time they do offer a lot more conventional. This is what can be considered as multi industry or network competition that can represent some limitations for new entries.

Porter's five driving forces referred to earlier part in the case of the restaurant in Tetovo have the following explanations as findings:

Industry and competitors: food industry if growing and will continue this trend in the future. The main competitors are bakeries and the shops that do offer the same products (food) like the proposed restaurant. 
Pressure from substitute products: include the large self-production and consumption by the families at home. The distinct feature of the restaurant to gain competitive advantage is to produce such a food for commercial/business purposes on daily basis, which is not possible by the families.

Bargaining power of suppliers: the restaurant will acquire the organic raw material directly from private households (milk cream, cheese, corns, fruits and vegetables) where we can check whether their farming is organic.

Bargaining power of buyers: the customers frequent the places where they can get certain organic and traditional food. At the restaurant they will have available all of them, thus in case they are not sure what exactly want to eat, they are more likely to chose the restaurant as they are sure it offers a greater variety.

Potential entrants: these are existing businesses (bakeries, certain restaurants) that may adopt their business strategy as well as new one like us. We have no information if someone is on the way to open this kind of restaurant, but if it is, we plan to maintain the leading position.

Of all products, food has the largest number of substitutes, especially when we think of just eating not to remain hungry. The challenge is with different kind of food and diets the customers like. With the increased need among the consumers for local organic food, the compettors may begin working in a similar strategy by offering substitutes at cheaper prices. A partial protection is the restaurant's application for licenses to certify many products with a detailed description how they are prepared and is branding all of them.

As the table in annex shows, gross sales, net sales, and gross profit constantly rose in the next three years. This may be in part of also rising prices of food, as measured by the Consumer Price Index (CPI). The CPI rose steadily since 2008, reaching 111.21 Index Points in June 2013 (the year in which the restaurant was established as a company), and dropping a little 109.55 Index Points (World Bank, 2016).

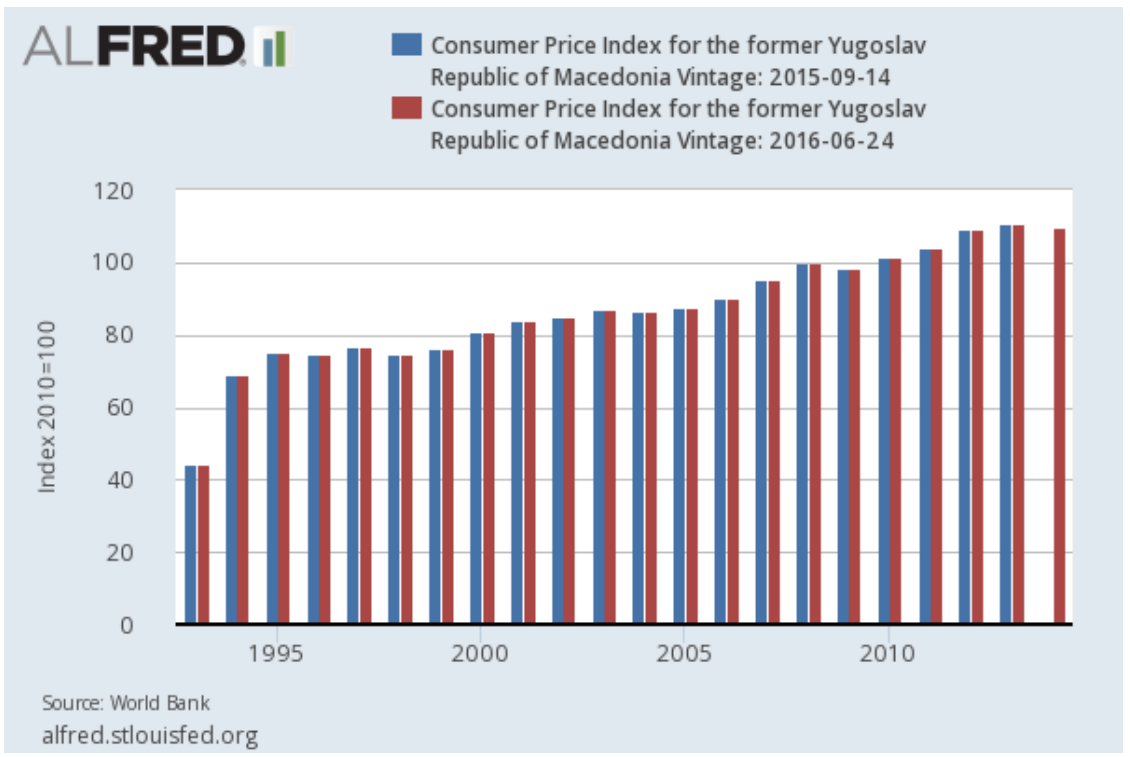

Figure 1: Consumer Price Index for the Republic of Macedonia, 1994 - 2015.

The general trend of rising food prices in the Republic of Macedonia, like in many parts of the world referred to earlier, acts as an incentive to entry this business. It was this incentive and the motive to make profit of three founders of the company in Tetovo dealing with manufacturing and serving of organic food. Total expenses by the end of the third year diminished by a factor of around 3 compared to the base year when they were very high as a result of starting up. The drivers of change will be to respond to the consumer behavior and habits. The response measures, depending on the success of the 
base in Tetovo, to open affiliations in other cities of Macedonia and use advertisements as part of tourism development. At present were unable to deduce the timing of these changes.

The restaurant is very attractive to the food industry as it brought a new way how organic food specific to a country can be channeled to the market for commercial purposes. It has begun to diversify the market for fast food which currently is dominated by bakeries, kebabs, hamburgers that can be found in every corner of Tetovo. In such a saturated market the customers are looking for alternatives which the restaurant is on the way to provide. Apart from customers, the restaurant under consideration rests on organic farming and processing that does not contribute to environmental pollution which is becoming a concern in modern times. The attractiveness if using local resources in producing and selling of organic food is also justified by the fact that Macedonia is large importer of food that is often associated with remarks by the customers and state controlling authorities as causing health concerns, e.g. importing of the meat whose analysis have frequently raised the concern of quality such as too conventional and even genetically-modified but without indicating in the label.

\section{Conclusion}

The demand for food in the Republic of Macedonia, like in any other countries, is increasing as are also increasing its prices. Businesses in food sector and consumers become aware in search of the food that brings more benefits on both sides. Organic farming and food is more preferred as it is healthier and ecologically accepted. As the prices rose sharply in recent year, it is an opportunity to engage in a business by opening a restaurant to offer exclusively organic food. The Polog region in the Republic of Macedonia has many such exclusive local organic foods that previously were produced at home by the families for self-consumption. However, these specificities are finding the way to the market through bakeries and various shops. The decision to open a restaurant of this type of food in the city of Tetovo was made after the founders found that a number of consumers on the rise, with a plan to expand its network of affliations. They invested their own capital and are getting the return on investment.

Market segmentation is currently focused in one city as a testing experience. The is a risk from new entries, but mainly in already existing market structure through bakeries and fast food shops. To gain a comparative advantage over these rivals, the restaurant in Tetovo is working on getting the certificates for many of the products with its own recipe and establish brands for each of them. The recipe then can be exported abroad to open similar restaurants, just as some well-known have done with their own.

The five forces as a model of competition, strategic actions, KSFs, drivers of change and attractiveness to industry revealed many advantages that the organic food restaurant has over its current and potential competitors. This does not imply that entering such a business is an easy task and the success is ahead. Possible changes should be carefully examined and managed. The exclusive restaurant of organic food in Tetovo should consider alternative strategies how to maintain the current leader position.

\section{References}

[1] Abd Ghani, D. K., Surina Nayan, Sheikh Ahmad I., Sheikh Mohd G., Latisha Asmaak S., and Suhaimi Nayan (2010), "Critical Internal and External Factors that affect Firms Strategic Planning", International Research Journal of Finance and Economics, Vol. 51, pp. 49-58.

[2] Armstrong, M. (1996), Management Processes and Functions, 1996, London: CIPD.

[3] Drinkwater, L. E. (2009), "Ecological Knowledge: Foundation for Sustainable Agriculture", in Francis, C. A. Ed., Organic Farming: The Ecological System, Madison: American Society of Agronomy Inc.

[4] European Commission (2011), The former Yugoslav Republic of Macedonia- Agriculture and Enlargement, European Commission, Brussels, available at: http://ec.europa.eu/agriculture/enlargement/countries/fyrom/profile en.pdf, accessed on 12 January 2017.

[5] Evans, A. (2008), "Rising Food Prices: Drivers and Implications for Development", New York University: Center on International Cooperation.

[6] Fitroy, P., Hulbert, J. M. and Ghobadian, A. (2012), Strategic Management: The Challenge of Creating Value, New York: Routledge.

[7] Godsey, J. A. (2010), 'Organic Restaurant Business Plan', Presented to the Faculty of the Agribusiness Department: California Polytechnic State University. 
[8] Johnston, A. E. (1986). "Soil organic-matter, effects on soils and crops", Soil Use Management , Vol. 2, No. 3, pp. 97-105.

[9] Hansen, B., Alroe, H. J. and Kristensen, E. S. (2001), "Approaches to assess the environmental impact of organic farming with particular regard to Denmark". Agriculture, Ecosystems \& Environment, Vol. 83, No. 1-2, pp. 11-26.

[10] Parmenter, D. (2007), Key Performance Indicators, Hoboken, NJ: Wiley.

[11] Porter, Michael E. (1980), Competitive Strategy: Techniques for Analyzing Industries and Competitors, New York: Free Press.

[12] Stolze, M., Piorr, A., Häring, A.M. and Dabbert, S. (2000), Environmental impacts of organic farming in Europe. Organic Farming in Europe: Economics and Policy Vol. 6. Universität Hohenheim: Stuttgart-Hohenheim.

[13] Wind, J. and Main, J. (1998), Driving Change, New York: Free Press.

[14] World Bank (2016), "Global Financial Development Database", Policy Research Working Paper 6175, Washington D.C.: World Bank.

\section{Appendix: Key indicators of the organic food restaurant in Tetovo}

Joint Stock Company (register)

3 co-owners

Renting Location in Central Tetovo - Annual $€ 15.000$

Indoors $100 \mathrm{~m}^{2}+$ outdoor $40 \mathrm{~m}^{2}+$ kitchen facility $20 \mathrm{~m}^{2}$ (total $160 \mathrm{~m}^{2}$ )

Funding: $€ 100000$ (each co-owner 33\%)

Initial Investment: $€ 100000$ (70,000 renovation+30,000 to run business in initial 3 months)

First year estimated expenses: $\sim € 120,000$ (e.g. monthly $\sim € 10,000$ )

1 Manager -1200

$€ 1000$

2 Chefs $-(2 \times 8000)$

$€ 1600$

4 Chefs assistant $(4 \times 400)$

$€ 1600$

4 Full time waiters $(4 \times 300)$

$€ 1200$

1 Oart time waiter ( $1 \times 200)$

$€ 200$

3 Bartenders $(3 \times 350)$

Accounting services - $200 \quad € 200$

Cleaning Service- $200 \quad € 200$

Utilities bills $-400 \quad € 400$

Maintenance - $200 \quad € 200$

Rent

First year turnover: $€ 130,000$

Meal served daily (average): 120 (€720)

Average Price of meals: $6 €$

Different soft Drinks served Daily Including coffee) : $€ 600$

Average Price of drink: $€ 1.5 €(€ 900)$

Different Alcoholic Drinks served Daily: $€ 200$

Average Price of drink: €2.5 (€500)

Average Total Turnover daily: $€ 2120$

Average Operating Days/Monthly : 26 days 
Average Monthly Turnover: $€ 55,120.00$

Average Turnover Yearly: $€ 661,440.00$

Average Expenses Monthly: $€ 10,000.00$

Cost of Goods sold:

Meals Approx: €3

$€ 360$

Non Alcoholic Drinks: $€ 0.7$

$€ 420$

Alcoholic Drinks: €1

$€ 500$

Daily Cost of Goods Sold:

$€ 1280$

Monthly COGS:

$€ 33,280.00$

YEARLY COGS:

Monthly Dispersion: $€ 661,440.00 / 12=€ 55,120.00$ Monthly

Income statement (in €)

\begin{tabular}{llll} 
INCOME & 2013 & 2014 & 2015 \\
\hline GROSS SALES & $659,400.00$ & $839,740.00$ & $1,000,577.00$ \\
Returns and Allow ances & $21,3507.00$ & $24,8469.30$ & $30,575.00$ \\
NET SALES & $445,893.00$ & 591270.70 & $970,002.00$ \\
Cost of Goods Sold & $206,596.90$ & $250,375.00$ & $304,613.0$ \\
GROSS PROFIT & $439,296.10$ & $440,895.70$ & 665,389 \\
EXPENSES (General/Administrative) & & & \\
Salaries andWages & $85,720.00$ & $92,200.00$ & $98,320.00$ \\
Employee Benefits & $4,680.00$ & $4,750.00$ & $5,316.00$ \\
Pay roll Taxes & $4,680.00$ & $4,770.00$ & $5,200.00$ \\
Accounting Services & $2,300.00$ & $2,350.00$ & $2,530.00$ \\
Cleaning Services & $2,300.00$ & $2,400.00$ & $2,400.00$ \\
Maintenance & $175,000.00$ & $1,750.00$ & $1,750.00$ \\
Rent & $13,450.00$ & $13,450.00$ & $13,450.00$ \\
Marketing and Adv ertisement & $4,750.00$ & $4,800.00$ & $4,000.00$ \\
Security & $2,400.00$ & $2,400.00$ & 0.00 \\
Utilities & $4,000.00$ & $4,600.00$ & $4,750.00$ \\
Telephone Service & $1,100.00$ & $1,000.00$ & 0.00 \\
Insurance & $1,650.00$ & $1,800.00$ & $2,000.00$ \\
Office Supplies & 955.00 & 860.00 & 880.00 \\
Postage and Shipping & 655.00 & 630.00 & 600.00 \\
TOTAL EXPENSES & $303,640.00 €$ & $137,760.00$ & $98,320.00$ \\
NET PROFIT & $133,474.42$ & $50,888.88$ & $183,864.02$ \\
\hline
\end{tabular}

